\title{
A megamouth shark (Lamniformes: Megachasmidae) in the Burdigalian of Belgium
}

\author{
Pieter J. DE SCHUTTER ${ }^{1} \&$ StiJn EVERAERT ${ }^{2}$
}

${ }^{1}$ Royal Belgian Institute of Natural Sciences, dept. of Palaeontology, scientific collaborator (volunteer contract), Vautierstraat 29, 1000 Brussels,Belgium; somniosus@skynet.be; corresponding author.

${ }^{2}$ Kapelleommegang 54, 9310 Herdersem,Belgium; stijn.everaert1@gmail.com.

ABSTRACT. The enigmatic megamouth shark is a rare occurrence in both Recent oceans and in the fossil record. A temporary construction site in the city of Antwerp (NW Belgium) gave the opportunity to study the poorly known early Miocene Kiel Sand Member of the Berchem Formation. In this Burdigalian deposit, a previously unknown fossiliferous horizon with Glycymeris and Cyrtodaria was sampled which contained a single Megachasma tooth. This specimen, attributed to Megachasma aff. pelagios by its resemblance with extant M. pelagios, is the first in situ record from un-reworked strata in Belgium. Only around a dozen fossil Megachasma teeth have been reported from Europe. It is concluded that a circumglobal megamouth population existed during the Burdigalian. Some evolutionary remarks are made.

KEYWORDS: Elasmobranchii, Megachasma, Miocene, Berchem Formation, Kiel Sand Member, North Sea Basin.

\section{Introduction}

The extant Megachasma pelagios Taylor, Compagno \& Struhsaker, 1983 is a large (up to ca. $5.5 \mathrm{~m}$ ), meso- to epipelagic, planktonivorous, filter-feeder shark with a nearly worldwide distribution in temperate and tropical waters (Compagno, 2001; Compagno et al., 2005). It was only discovered in 1976 near Hawaii and considered as one of the most spectacular zoological discoveries in the twentieth century (e.g. Berra, 1997). By its unusual appearance and oversized mouth, a new family, genus and species was erected. Since its discovery, only around a hundred individuals have been observed or caught (Liu et al., 2018). Watanabe \& Papastamatiou (2019) compile 117 sightings; mainly in the Pacific, occasionally in the Indian or Atlantic Ocean, but this shark has never been spotted in the North or Mediterranean Sea (Fernando et al., 2015; Liu et al., 2018).

The published fossil record is equally very poor. Fossil megachasmids have only been reported sporadically and are mostly based on one or two teeth: in Europe (Keupp \& Bellas, 2002; De Schutter, 2009; Reinecke et al., 2011; Spadini \& Manganelli, 2015; Shimada \& Ward, 2016), Asia (Tomita \& Yokoyama 2015), North America (Purdy et al., 2001; De Schutter, 2009) and South America (Gonzalez-Barba \& Thies, 2000; De Schutter, 2009; Cappetta, 2012; Landini et al., 2019). An exception is the large number of megachasmid teeth reported from late Oligocene to early Miocene deposits in western USA (California and Oregon), already known for several decades (e.g. Phillips et al., 1976), but only recently formally described by Shimada et al. (2014) as Megachasma applegatei. So far, the genus Megachasma consists of three nominal species: the extant M. pelagios, the late Oligocene - early Miocene M. applegatei and the late Eocene M. alisonae Shimada \& Ward, 2016, the oldest record, represented by a single tooth from the Priabonian of Denmark.

Since the discovery of fossil teeth of Megachasma in Belgium (De Schutter, 2009), several dozens of specimens have been recovered from another ex situ sand deposit around the town of Hoevenen (municipality of Stabroek, province of Antwerp) (Everaert, 2014). However, very recently an additional single specimen has been found in the early Miocene Kiel Sand Member of the Berchem Formation, representing the first Miocene in situ record of teeth of this genus in Belgium and a possible origin for the ex situ specimens, as suggested by Everaert (2014).

\section{Locality}

The Megachasma tooth was found during the excavating of several underground floors for the new Argenta building, located between the Van Diepenbeeckstraat and the Lamorinièrestraat in the Antwerp district of Antwerp city, northwestern Belgium (WGS84 coordinates $51^{\circ} 12^{\prime} 21.8^{\prime \prime} \mathrm{N} 4^{\circ} 25^{\prime} 26.6$ 'E), approximately $1 \mathrm{~km}$ north of the Post X outcrop (Everaert et al., 2019) (Fig. 1). The excavation reached a depth of almost $15 \mathrm{~m}$, exposing more than $10 \mathrm{~m}$ of glauconitic sediments of the Berchem Formation.
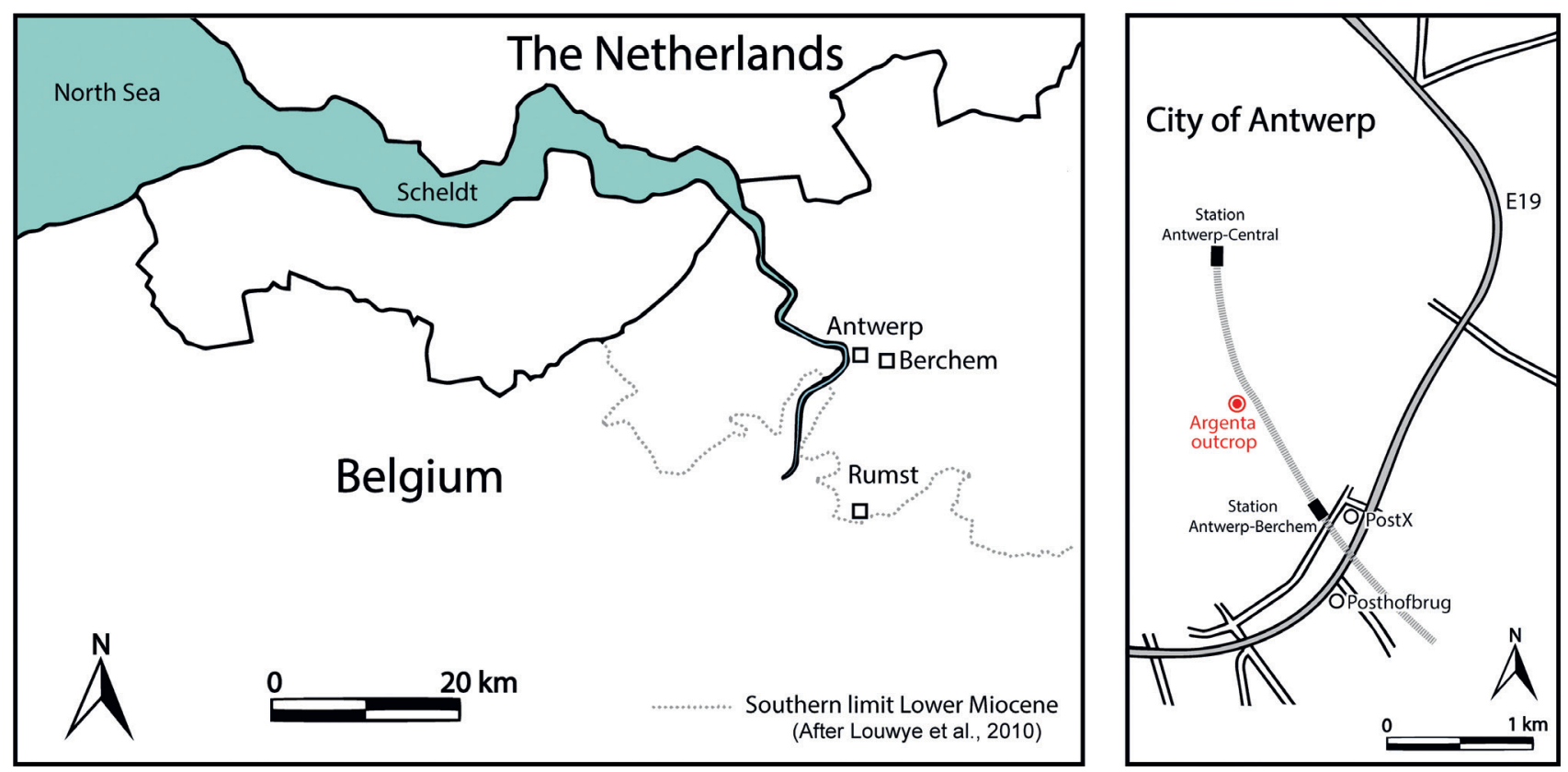

Figure 1. Map of the Antwerp area (left) and location of the Argenta exposure (right). 


\section{Stratigraphy of the Argenta exposure}

\subsection{Introduction}

In the Antwerp area, the Berchem Formation is defined by De Meuter \& Laga (1976) and divided into the Edegem, Kiel and Antwerpen Sand Members. An early Burdigalian age is attributed to the Edegem Sand Member and a Burdigalian age to the Kiel Sand Member (Louwye et al., 2000). The Antwerpen Sand Member is separated from the latter by a hiatus at the lowermiddle Miocene transition. The deposition of the Antwerpen Sand Member took place in the Langhian (latest Burdigalian?) - middle Serravalian interval (Louwye et al., 2000; Louwye et al., 2010).

\subsection{Lithology of the Argenta exposure (Fig. 2, Plate 1)}

From the bottom of the construction pit, unit 1 consists of ca. $2 \mathrm{~m}$ of grey, glauconitic sand with trace fossils, overlain by a $1.20 \mathrm{~m}$ thick bed of dispersed double-valved, Glycymeris baldii Glibert \& Van de Poel, 1965, sometimes partly covered with barnacles (unit 2). The top of unit 2 is located at $11.80 \mathrm{~m}$ below street level. It is followed by ca. $3 \mathrm{~m}$ of bioturbated sand (unit 3).

Unit 4 is a $10-15 \mathrm{~cm}$ thick layer of coarse glauconitic sand with coarse quartz grains and abundant valves of Glycymeris baldii Glibert \& Van de Poel, 1965 with convex-up orientation. Characteristic for this horizon is the relatively high occurrence of Cyrtodaria angusta (Nyst \& Westendorp, 1839), and the presence

\begin{tabular}{|l|c|c|}
\hline LITHOSTRATIGRAPHY & PROFILE & DEPTH \\
\hline
\end{tabular}
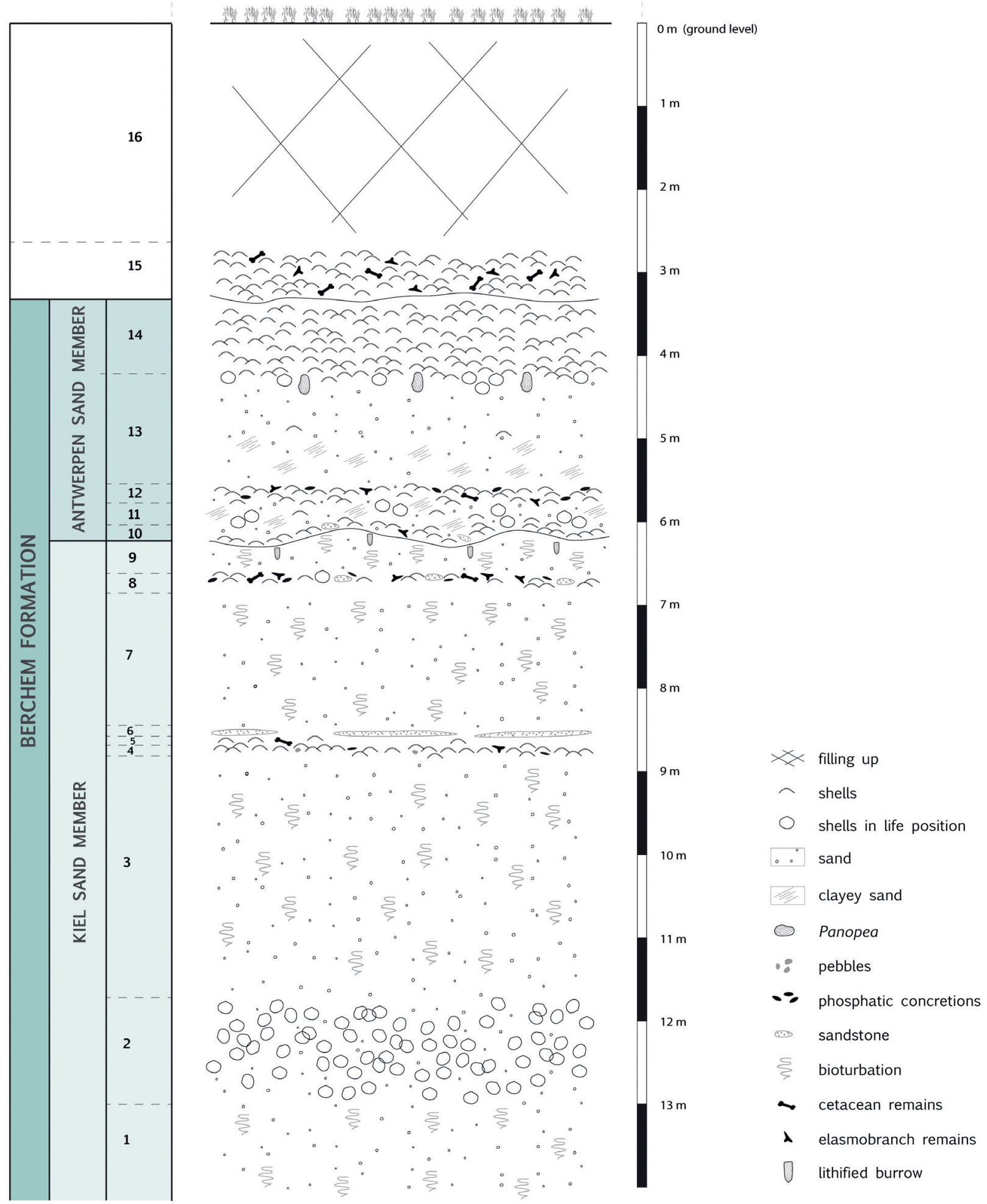

Figure 2. Lithostratigraphy of the Argenta exposure. 


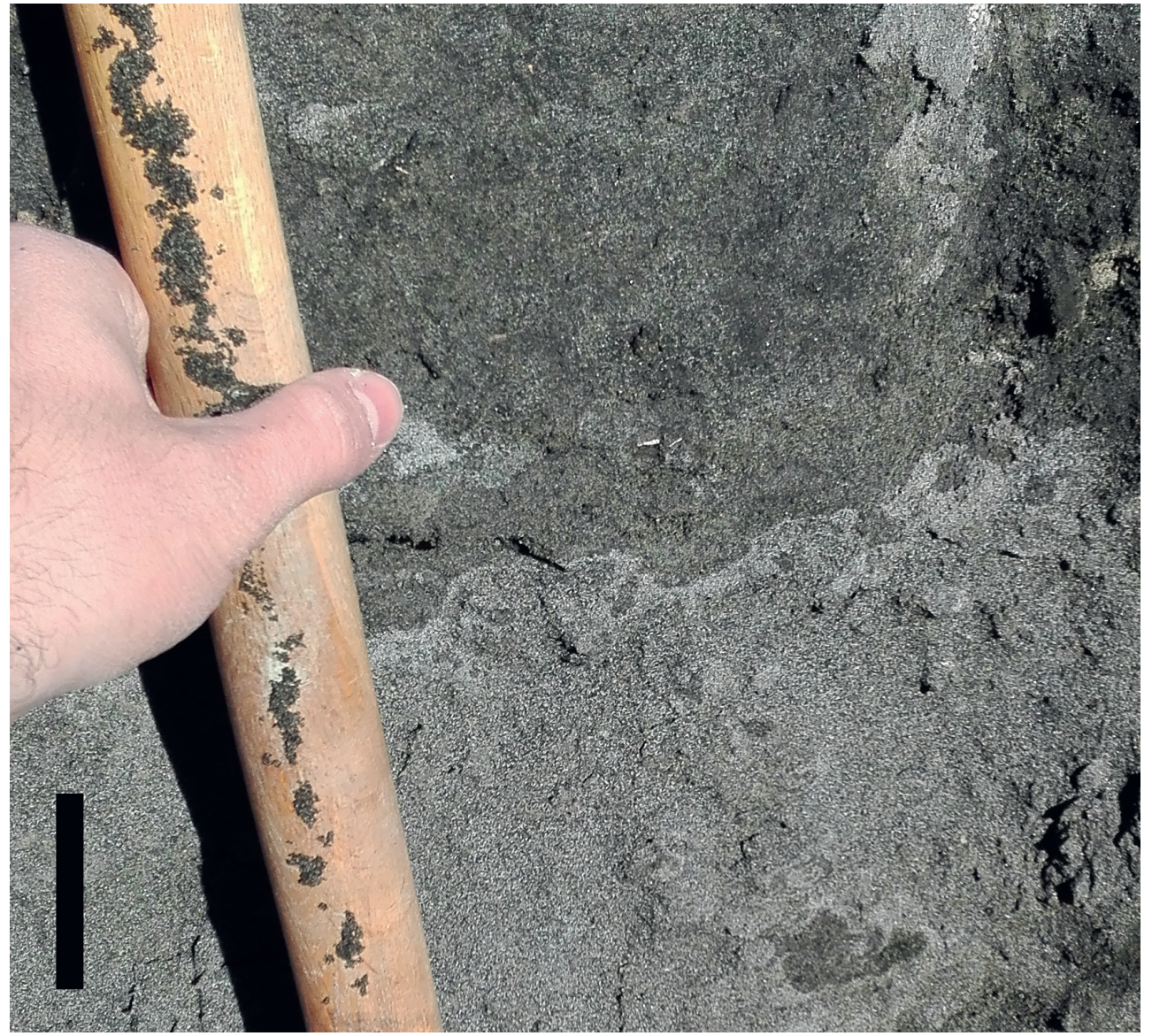

Figure 3. The sharp lithological boundary between the blackish, clayey base of the Antwerpen Sand Member (unit 10) and the underlying top of the greyish, coarser grained Kiel Sand Member (unit 9). Scale bar $5 \mathrm{~cm}$.

of Glossus burdigalensis cypriniformis (Nyst in Dewalque, 1868) and some Ostreoidea (small Neopycnodonte sp. and Cubitostrea digitalina (Eichwald, 1830 emend. DuBois de Montperreux, 1831)). The preservation of calcareous fossils is poor due to decalcification. A few rounded, brown-grey, phosphatic concretions and some small, black pebbles occur. This level yielded several cetacean remains and a small shark assemblage including the Megachasma tooth (present study) and is located around 8.50 to $8.70 \mathrm{~m}$ below street level (Plate 1C).

A thin unit of max. $5 \mathrm{~cm}$ of coarse sand (unit 5) separates this shell level from a sandstone hardground (unit 6) which has a more or less continuous course with short interruptions. The lithology, fauna and taphonomy of unit 6 closely resembles the sandstone bed of Herman \& Marquet (2007), the fauna of unit 6 only differs by the presence of Turritella eryna (d'Orbigny, 1852).

After two metres of strongly bioturbated, grey, medium-fine to coarse, loose sand (unit 7) (Plate 1B), a 5-15 cm thick horizon of grey, medium-fine to coarse sand with local concentrations of mainly decalcified and very fragile Cordiopsis polytropa nysti (d'Orbigny, 1852), many brown-grey rounded phosphatic concretions, numerous well-preserved elasmobranch teeth, cetacean remains and pieces of sandstone occurs (unit 8). Unit 8 is covered by ca. $50 \mathrm{~cm}$ of bioturbated, grey, medium-fine to coarse sand (unit 9).

At ca. $6 \mathrm{~m}$ below ground level, a sharp continuous lithological boundary has been observed between the grey, coarser grained unit 9 and the dark, clayey and rather fine grained unit 10 (Fig. $3)$. We observe (1) a strong difference in colour appearance (particularly visible when the sand is completely dry), (2) the undulating course of unit 10 through load casting effects due to its higher density than the coarser sand (unit 9) beneath it, and (3) the occasional presence of small flat sandstones $(5-10 \mathrm{~cm})$ just above the boundary and some big lithified burrows just below the boundary.

Unit 10 is formed by a thin $(10 \mathrm{~cm})$ undulating bed of Glycymeris baldii Glibert \& Van de Poel, 1965 valves resting on a small band of dark, very glauconitic, rather fine, clayey sand. We also note the presence of some large Neopycnodonte navicularis (Brochi, 1814), a few Cordiopsis polytropa nysti (d'Orbigny, 1852) and a fragment of Turritella eryna (d'Orbigny,
1852). Few shark teeth occur. Unit 11 consists of 40 to $60 \mathrm{~cm}$ dark, very glauconitic, rather fine, clayey sand with dispersed, large double-valved Glycymeris baldii Glibert \& Van de Poel, 1965. The overlying unit 12, with a thickness of $20 \mathrm{~cm}$, consists of dark, very glauconitic, rather fine clayey sand with Glycymeris baldii Glibert \& Van de Poel, 1965 without preferred orientation. It further contains Patinopecten brummeli (Nyst, 1864), several Turritella eryna (d'Orbigny, 1852), Glossus lunulatus lunulatus (Nyst, 1835), Cordiopsis polytropa nysti (d'Orbigny, 1852), dark green to black phosphatic concretions, shark teeth and cetacean remains. This horizon is followed by $120 \mathrm{~cm}$ of medium-fine, very glauconitic sand (unit 13) which is coarsening upward and becoming less clayey near the top. The upper $20 \mathrm{~cm}$ of unit 13 contains Panopea kazakovae Glibert \& Van de Poel, 1966 in life position.

Unit 13 is followed by a $90 \mathrm{~cm}$ massive shell crag containing convex-up oriented valves of Glycymeris baldii Glibert \& Van de Poel, 1965 in a matrix of medium-fine, very glauconitic sand (unit 14). Double-valved Glycymeris occur at the base of the shell crag.

Locally, the upper part of the glauconitic sands (units 13 and 14) may have a rusty aspect due to post depositional oxidation (varying in depth) of the glauconitic sands. The Miocene sands are covered by a $70 \mathrm{~cm}$ thick Quaternary, loamy shell crag (unit 15) containing reworked Neogene fossils and ca. $280 \mathrm{~cm}$ of disturbed soil with brick fragments (unit 16).

\subsection{Lithostratigraphy of the Argenta exposure (Fig. 2, Plate 1)}

Two Miocene members are recognized, the Kiel and the Antwerpen Sand Members. The Kiel Sand Member (unit 1-9) consists of at least $8 \mathrm{~m}$ of medium-fine to coarse grained, grey, loose glauconitic sand with many quartz grains and abundant trace fossils. Due to decalcification, the molluses in the Kiel Sand Member are very fragile and not well preserved compared to those in the overlying Antwerpen Sand Member. The Antwerpen Sand Member (unit 10-14) reaches a total thickness of ca. 2.5 to $2.8 \mathrm{~m}$ and consists of dark-coloured to black, fine to mediumfine grained, very glauconitic sand with abundant shell horizons. According to a geothermal rinsing drilling at the Argenta outcrop (Van Dijck, 2018), the base of the Berchem Formation, resting 
on the Oligocene Boom Clay Formation, lies $26 \mathrm{~m}$ below street level, thus still $11 \mathrm{~m}$ deeper than the base of the pit. The lowest 4 $\mathrm{m}$ are described as fine, clayey sediments and possibly belong to the Edegem Sand Member.

\subsection{Discussion}

De Meuter \& Laga (1976) define the Kiel Sand Member as a greygreen, medium fine to coarse grained, loose sandy unit devoid of fossils, restricted to the central and southern part of Antwerp and becoming fossiliferous to the north and east where it becomes indistinguishable from the superjacent Antwerpen Sand Member. The latter observation is largely based on the section 'A.K Antwerpen - Kievitstraat' in the north of the city, a temporary excavation (1965-1966) enclosed by the Lange Kievitstraat and the Ploegstraat. While this section is entirely interpreted as Antwerpen Sand Member by De Meuter et al. (1976), Louwye et al. (2000) correlated the lower part with parts of the Kiel Sand Member from sections in the south of Antwerp. A hiatus of ca. 2 million years was noticed between the lower and upper parts of the Kievitstraat section.

Our observations at the Argenta exposure prove the need to redefine the Kiel Sand Member as suggested by Louwye et al. (2000). While we agree with De Meuter \& Laga (1976) that the Kiel Sand Member contains fossils towards the north, our observations contradict De Meuter \& Laga (1976) in the fact that, based on lithology, the Kiel Sand Member is clearly distinguishable from the overlying Antwerpen Sand Member (Fig. 3), similar as seen in more southern exposures (e.g. Louwye et al, 2010; Hoedemakers \& Dufraing, 2018; Everaert et al., 2019) and more eastern localized sections (Tweelingenstraat, pers. obs. 2019, unpublished data).

In dry conditions, the Kiel Sand Member is grey and lighter in colour than the Antwerpen Sand Member due to a relatively higher content of quartz grains. The Kiel Sand Member is coarser grained than the base of the Antwerpen Sand Member, in which undulating loadcasting structures can arise due to the difference in density (Everaert et al, 2019). Also, the coarse-grained Kiel Sand Member has a loose structure, which makes it more quickly eroded by wind and rain, in contrast to the clayey, finer-grained base of the Antwerpen Sand Member. The Kiel Sand Member shows abundant trace fossils throughout the whole profile in all known sections, so does the lower part of the Kievitstraat section (De Meuter et al., 1976).

Van den Bosch (1966), describing the same exposure as De Meuter et al. (1976), did notice a change in lithology at ca. $3.70 \mathrm{~m}$ below the top of the Miocene: 'Medium fine, clayey glauconitic sand' with shells are overlying several metres of 'medium fine, quartz rich, glauconitic sand' with only some traces of shellgrit and a small level of 'medium fine to locally very coarse sand with fine pebbles, many bad preserved shells (big Glycymeris)' at its base. The lithology of the latter level is similar to Unit 4 of the Argenta section.

\subsection{Palaeo-environment of the Megachasma bearing horizon (unit 4, Plate 1)}

The Kiel Sand Member has been deposited in a shallow, coastal shelf sea (Louwye et al., 2000; Everaert et al., 2019). Aside of the single Megachasma specimen, the shark fauna of unit 4 is similar to the fauna of unit 8 (Cordiopsis horizon) as described by Everaert et al. (2019) from the nearby Post X exposure. An extensive molluscan fauna is present in unit 4, e.g. Glycymeris baldii Glibert \& Van de Poel, 1965, Cyrtodaria angusta (Nyst \& Westendorp, 1839), Cordiopsis polytropa nysti (d'Orbigny, 1852), Glossus burdigalensis cypriniformis (Nyst in Dewalque, 1868), with some species previously unknown for the Kiel Sand Member (Herman \& Marquet, 2007), e.g. Cubitostrea digitalina (Eichwald, 1830 emend. Dubois de Montperreux, 1831), Patinopecten brummeli (Nyst, 1864), Venus (Ventricoloidea) multilamella (Lamarck, 1818) s. lat. and some small Neopycnodonte. Many specimens of G. baldii Glibert \& Van de Poel, 1965 from the Kiel Sand Member seem more convex and have a slightly thicker shell than those from the overlying Antwerpen Sand Member. A detailed description of the fauna of unit 4 is in progress (Everaert et al., in prep). All the valves of Glycymeris show traces of abrasion, the crenate margin and the upper region around the umbo are often damaged. The shells regularly show barnacles and ichnofossils of the spionid worm Polydora sp., which usually occur in marine environments with soft, muddy seafloors and maximal water depths of $25 \mathrm{~m}$ (Marquet, 1984). Shark teeth often show signs of bio-erosion and brown-grey phosphatic concretions regularly cover (parts of) the roots. Some show traces of transport. These taphonomic characteristics may indicate relatively low sedimentation rates (Nichols, 2009). The convex side up orientation of the Glycymeris valves may be an indicator of storm transport (Cleveringa \& Schrijver, 2000).

\section{Material and methods}

Due to the rapid progress of the excavation and the strict safety regulations, the construction pit could only be accessed on April 17,2019 . The sampled horizon was only visible for a very short time at the bottom of the pit. Roughly 300 litres of sediment from unit 4, under the sandstone lithifications, were sieved onsite through a $5 \mathrm{~mm}$ mesh, which resulted in the discovery of the single Megachasma specimen. Because of the absence of water in the pit, a sediment sample of 25 litres was taken home to be sieved through a $0.8 \mathrm{~mm}$ mesh. Descriptions about the granulometry are visually assessed on the field, these are no lab measurements.

Institutional abbreviations. RBINS, Royal Belgian Institute of Natural Sciences, Brussels, Belgium.

Other abbreviations. TH, total tooth height; TW, total tooth width; $\mathrm{CH}$, crown height; $\mathrm{CT}$, crown thickness; CW, crown width; RL, root length; RW, root width; TT, total tooth thickness (for dental measurements, see Shimada et al., 2014, fig. 6A).

\section{Systematic palaeontology}

Class Chondrichthyes Huxley, 1880

Order Lamniformes Berg, 1958

Family Megachasmidae Taylor, Compagno \& Struhsaker, 1983

Genus Megachasma Taylor, Compagno \& Struhsaker, 1983

Megachasma aff. pelagios Taylor, Compagno \& Struhsaker, 1983

(Plate 2A-F)

Material examined. One tooth, IRSNB P 9946, collected by the junior author and donated to the Royal Belgian Institute of Natural Sciences (RBINS), Brussels, Belgium, palaeontological collections.

Description. Large sized tooth with TH of $10.7 \mathrm{~mm}$, TW of $7.2 \mathrm{~mm}$, and TT of $7.7 \mathrm{~mm}$. The crown is apicobasally short with $\mathrm{CH}$ of $8.8 \mathrm{~mm}, \mathrm{CW}$ of $4.8 \mathrm{~mm}$, and CT of $2.9 \mathrm{~mm}$. The crown is strongly lingually directed, giving the tooth a hooked appearance; the cusp almost parallels the lingual attachment surface of the root. The crown is slightly asymmetrical with a weak distal inclination of the cusp. The strongly convex lingual crown surface is smooth. The convex labial crown face exhibits some poorly discernible short vertical ridges along its base. The smooth mesial and distal cutting edges almost reach the base of the crown. In labial view, the crown is mesiodistally slightly wider at its base and narrows gradually towards the apex. Marginal lateral extensions of the crown base with rounded shoulders extend shortly onto each root lobe on labial face. There are no lateral cusplets. The labial crown surface exhibits some wear facets. The massive bilobate root has an equal length (RL) and width (RW) of $7.2 \mathrm{~mm}$. The lingual protuberance is strong. The root lobes are short and rounded, only slightly extending below the attachment surface, and connected by a very poor basal concavity. In basal view, the flat or slightly convex attachment surface of the root is D-shaped. As the root shows traces of pre-burial abrasion, a nutrient groove (if present) or scattered foramina are not discernable.

Differential diagnosis. Isolated Megachasma teeth are difficult to attribute to a specific tooth position (e.g. Shimada et al., 2014). By its larger size, closely spaced root lobes, and mesiodistally rather narrow root and crown base, IRSNB P 9946 could be attributed to an anterior tooth position. The cusp almost parallels the lingual attachment surface of the root, as observed on the first and second teeth of both jaws in extant $M$. pelagios 
(Yabumoto et al., 1997). The crown is slightly distally inclined, suggesting an upper right or lower left tooth.

Based on dental morphology, Cenozoic megamouth sharks can be divided in two groups (De Schutter, 2009): (1) Megachasma sp., characterized by smaller teeth and the general presence of lateral cusplets and (2) Megachasma cf. pelagios (= 'M. cf. $M$. pelagios' of Shimada et al., 2014, see Bengtson, 1988; Sigovini et al., 2016), characterized by larger teeth, a general absence of lateral cusplets, and a more elongated crown. Shimada et al. (2014) and Shimada \& Ward (2016) accepted these two broad categories and referred to megachasmid teeth with prominent lateral cusplets as "applegatei-grade" Megachasma and all other fossil megachasmid teeth with no or rudimentary lateral cusplets as "pelagios-grade" Megachasma. The first category comprises both $M$. alisonae and M. applegatei.

By the considerable variation in dental morphology (e.g. Purdy et al., 2001; De Schutter, 2009; Shimada et al., 2014), identifying a single isolated tooth might prove to be very difficult or even impossible. Shimada et al. (2014) used quantitative analysis to differentiate the late Oligocene and earliest Miocene $M$. applegatei from the extant M. pelagios and observed a substantial difference in crown height/crown width ratios. M. pelagios tends to have more slender crowns compared to $M$. applegatei that has crowns with similar height and width. But the morphological and size ranges of M. applegatei and M. pelagios still overlap.

If IRSNB P 9946 with a $\mathrm{CH} / \mathrm{CW}$ ratio of 1.83 and a RL/RW ratio of 1 is plotted (see Shimada et al., 2014, fig. 6B-C), it shows up in the range of Megachasma pelagios Taylor, Compagno \& Struhsaker, 1983. The crown slenderness $(\mathrm{CH} / \mathrm{CW}$ ratio) even falls well inside $M$. pelagios interquartile range. Unfortunately, teeth of extant M. pelagios are poorly illustrated in the available literature (Herman et al., 1993; Yabumoto et al., 1997; De Schutter, 2009; Watanabe \& Papastamatiou, 2019). Teeth of $M$. pelagios are small, ca. 5-10 mm (Compagno, 1990; Yabumoto et al., 1997; De Schutter, 2009), have a broad based, elongated crown (Herman et al., 1993), with a narrowed and sometimes stretched-out apical part (Yabumoto et al., 1997). The root is long, broad and flat with a prominent lingual protuberance and very short lobes (Compagno, 1990). IRSNB P 9946 resembles $M$. pelagios by the lack of cusplets, the well-developed lingual root protuberance and the short and barely extended root lobes connected by a very poor basal concavity. The basal attachment surface of IRSNB P 9946 is clearly D-shaped, labiolingually and mesio-distally of the same size, and similar as observed on $M$. pelagios. IRSNB P 9946 only differs from $M$. pelagios by having a shorter and less narrowing crown, without the elongated apical part.

IRSNB P 9946 measures $10.7 \mathrm{~mm}$ (TH), much larger than the average tooth height of $M$. applegatei, where only ca. $4.5 \%$ of the 67 type specimens exceeds $10 \mathrm{~mm}$, but this might be expected by the younger age of IRSNB P 9946 and the observed trend during the Miocene in acquiring larger teeth. The size of IRSCNB P 9946 is intermediate between the late Oligocene to early Miocene $M$. applegatei and the late Miocene to early Pliocene Megachasma cf. pelagios. Compared to IRSNB P 9946, teeth of M. applegatei generally possess lateral cusplets, have a shorter crown, and a root with a less pronounced lingual protuberance, longer and wellseparated lobes and a more triangular basal attachment surface.

IRSNB P 9946 represents an intermediate morphology between M. applegatei and M. pelagios, but is much closer to the latter than the former. This Burdigalian specimen might belong to a "pelagios-grade" Megachasma. By the considerable variation in dental morphology and based on a single specimen, IRSNB P 9946 is tentatively assigned to Megachasma aff. pelagios Taylor, Compagno \& Struhsaker, 1983. Hopefully this new and yet poorly sampled Burdigalian horizon will reveal additional specimens in the future.

Discussion. Only two nominal fossil megamouth species are described so far. Megachasma applegatei Shimada, Welton \& Long, 2014, based on an extensive set of 67 type specimens, collected from late Chattian to Aquitanian deposits in California and Oregon (USA). The teeth of this species vary in size; lateral cusplets vary in presence, number and morphology and also the root's nutrient groove exhibits a wide variation. Teeth of this species are further characterized by having a short crown, a strong lingual inclination of the cusp and a massive bilobate root with well-separated lobes and a strong lingual protuberance. A single late Eocene specimen has been described from the Priabonian of Denmark: Megachasma alisonae Shimada \& Ward, 2016. This tooth only measures $4 \mathrm{~mm}$ in height and differs from $M$. applegatei in having a smaller lingual root protuberance, larger lateral cusplets and more widely spaced root lobes (Shimada \& Ward, 2016).

In Europe, in addition to the Belgian specimens (De Schutter, 2009; present study), Neogene megamouth teeth are only reported from Germany, Greece and Italy. Reinecke et al. (2011) attribute a single specimen, recovered from late Burdigalian sediments in Germany, to Megachasma sp.; Keupp \& Bellas (2002) figured a single megamouth tooth from the Tortonian of Crete (Greece), incorrectly identified as a Hexanchus symphyseal (see De Schutter, 2009) and finally, Spadini \& Manganelli (2015) ascribe a single tooth $(\mathrm{TH}=14.8 \mathrm{~mm})$ found in the Zanclean of Italy to "Megachasma cf. M. pelagios" Taylor, Compagno \& Struhsaker, 1983.

From North America, Megachasma sp. has been reported from the Neogene of the Lee Creek Mine, North Carolina (Purdy et al., 2001) and Florida (De Schutter, 2009). Purdy et al. (2001, fig. 21) figured five teeth from the Zanclean Yorktown Formation of Lee Creek Mine, North Carolina (USA), of which the largest tooth measures $17 \mathrm{~mm}$ in height. The authors further observed a considerable morphological variation and a resemblance with extant M. pelagios. The small specimen (op. cit., fig. $21 \mathrm{~g}-\mathrm{h}$ ) is questionable and might represent a Galeocerdo or Physogaleus symphyseal tooth. The two smaller teeth recovered from the Burdigalian Pungo River Formation are more difficult to evaluate (Purdy et al., 2001, fig. 21i-m); also specimen USNM 459822 might represent a Galeocerdo or Physogaleus symphyseal tooth.

In South America, Megachasma teeth have been found in the Miocene of Chile (De Schutter, 2009; Cappetta, 2012), Mexico (Gonzalez-Barba \& Thies, 2000) and Peru (Landini et al., 2019). Tomita \& Yokoyama (2015) reported the only reliable record from Asia with a single specimen from the Late MiocenePliocene interval of Okinawa Island, Japan. This specimen measures almost $11 \mathrm{~mm}$ in height, lacks lateral cusplets and displays a weakly bilobate root. It is attributed to "Megachasma cf. M. pelagios".

Lateral cusplets are present in all known megamouth species (e.g. Herman et al., 1993; Shimada et al., 2014). The single late Eocene specimen of Megachasma alisonae has lateral cusplets and teeth of the late Chattian - Aquitanian M. applegatei tend to have lateral cusplets on a regular basis, but since the Burdigalian, lateral cusplets seem to become very uncommon. While ca. $92.5 \%$ of the type specimens of $M$. applegatei possesses at least one lateral cusplet (Shimada et al., 2014), it's very remarkable that all known Burdigalian Megachasma teeth are devoid of lateral cusplets. But with only four reliable teeth, the sample size is very small. The fossil record indicates a circumglobal megamouth population during the Burdigalian with occurrences in Belgium, Germany, USA and Peru (Purdy et al., 2001; Reinecke et al., 2011; Landini et al., 2019; present study). Despite the lack of cusplets, the Burdigalian specimens from Germany and Peru (Reinecke et al., 2011; Landini et al., 2019) are referred to Megachasma cf. applegatei Shimada, Welton \& Long, 2014, principally by the short crown and the root with well-developed lobes and a roughly triangular shaped basal attachment surface. The two specimens from the Burdigalian Pungo River Formation (Purdy et al., 2001, fig. 21i-m) and the second Burdigalian specimen from Peru (Landini et al., 2019, fig.3F-H) are difficult to evaluate and might belong to different genera.

Apart of the difference in morphology and size of the crown, and the loss of cusplets, also the shape of the root is an important characteristic to distinguish "applegatei-grade" from "pelagiosgrade" Megachasma. Teeth of the former possess roots with welldeveloped and elongated root lobes and a more or less triangularly shaped basal attachment surface. To the contrary, teeth of the latter have more compressed roots, with strongly reduced lobes, a stronger lingual protuberance and a more square or D-shaped attachment surface. The basal root cavity almost disappears. 
The large megamouth teeth found in late Miocene to early Pliocene sediments worldwide (e.g. Chile, North Carolina, Florida, Italy, Greece and Japan) with strongly compressed root and no or rudimentary lateral cusplets are referred to as Megachasma cf. pelagios Taylor, Compagno \& Struhsaker, 1983, or early M. pelagios, and appear to be giant versions of modern teeth; apart from their size, these teeth are almost identical (De Schutter, 2009). Many shark species attained a larger size during the Late Miocene - Early Pliocene interval (e.g. Purdy et al., 2001; Adnet \& Martin, 2007; Chandler et al., 2006). However, teeth of early $M$. pelagios (= M. cf. pelagios) have roots with a very strong lingual protuberance, highly apico-basally compressed creating a large and flat attachment surface (e.g. De Schutter, 2009 , plate $10 \mathrm{M}-\mathrm{V}$ ); while the root protuberance on teeth of extant M. pelagios is less lingually developed and less apicobasally compressed (e.g. Yabumoto et al., 1997; De Schutter, 2009, plate $11 \mathrm{M}-\mathrm{R})$.

Belgian specimens of De Schutter (2009). De Schutter (2009) described seven Megachasma teeth, all but one originating from the Deurganckdok (Doel, Antwerp harbour, province of OostVlaanderen). One specimen was discovered in situ in the basal gravel of the Kattendijk Formation (De Schutter, 2009, plate 7A-F), while five other teeth were found in mixed sand deposits from the same large excavation (De Schutter, 2009, plates 2-6). In the Deurganckdok, the transgressive base of the early Pliocene Kattendijk Formation (Zanclean) was located on top of the early Burdigalian Edegem Sand Member of the Berchem Formation, or immediately on the abraded top of the Oligocene (without intermediate Miocene). Locally the Edegem Sand Member was covered or incised by the Burdigalian Kiel Sand Member (Herman \& Marquet, 2007).

Surprisingly, a new sand deposit around the town of Hoevenen (municipality of Stabroek, province of Antwerp), with sediments originating from the Churchill harbour dock, yielded several dozens of megamouth teeth. Everaert (2014) pointed out the unique character of this deposit and evoked an early Miocene age for part of the recovered elasmobranch remains.

In addition, the recent discovery of a Burdigalian horizon with elasmobranch remains (unit 4, Fig. 2), that yielded this single megamouth specimen (present study), could represent a possible source for the specimens in De Schutter (2009), which would strongly narrow down their stratigraphic range. However, given the poor chronostratigraphic constraint of the deposit that yielded these teeth, it cannot be excluded that more than one (chrono) species is present in the sample. On the other hand, the middle Miocene Antwerpen Sands (pers. obs.), the late Miocene Deurne Sands (Hoedemakers \& Dufraing, 2015) and early Pliocene Kattendijk Formation (Herman et al., 1974) have failed to yield a single megamouth tooth.

Shimada et al. (2014) provisionally included the Belgian specimens of De Schutter (2009) in M. applegatei. However, when comparing these teeth to $M$. applegatei and extant specimens, De Schutter (2009) already noted the intermediate morphology of the Belgian specimens and recognised some evolutionary trends: the crowns are getting taller and more elongated. The cusplets, root lobes and nutrient groove become reduced and almost disappear. The root becomes more apico-basally compressed, producing a larger protuberance and a flat attachment surface (De Schutter, 2009, table 2). While most of the Belgian specimens possess at least a marginal distal or mesial cusplet, these cusplets are less developed than observed on M. applegatei and are in the process of disappearing.

Variation in dental morphology. An interesting observation is the considerable variation in dental morphology within the type series of M. applegatei (Shimada et al., 2014). While the average height is $6.6 \mathrm{~mm}$, one specimen even attains $14.7 \mathrm{~mm}$ in height (LACM 122197; Shimada et al., 2014, fig. 4BI). Shimada \& Ward (2016) suggest that this particular tooth may actually belong to a "pelagios-grade" Megachasma. This specimen is surprisingly large and indistinguishable from teeth of the extant M. pelagios and early $M$. pelagios like the single Pliocene specimen from Italy (cf. Spadini \& Manganelli, 2015). Also specimen LACM 122130 (Shimada et al., 2014, fig. 4A) is very similar to M. pelagios, except for the less pronounced lingual root protuberance.
IRSNB P 9946 is attributed to Megachasma aff. pelagios while other Burdigalian specimens, e.g. from Germany and Peru (Reinecke et al., 2011; Landini et al., 2019), are referred to Megachasma cf. applegatei Shimada, Welton \& Long, 2014. This supports the suggestion by Shimada \& Ward (2016) that the divergence of "pelagios-grade" Megachasma from M. applegatei took place during the early Miocene and thus that the "applegateigrade" and "pelagios-grade" Megachasma cohabited at that time. Until now, the oldest known record for the "pelagios-grade" Megachasma is the single Tortonian specimen from Greece (Keupp \& Bellas, 2002).

The Belgian megamouth teeth of De Schutter (2009), even in such limited sample $(n=7)$, also show a remarkable variability. This variation can be explained by a possible presence of more than one (chrono)species in the sample, given the nature of the deposits that yielded these teeth. On the other hand, it is plausible that all specimens do originate from the Burdigalian Kiel Sand Member. While specimens BG01 (De Schutter, 2009, plate 2AG) and LA01 (op. cit., plate 7A-F) have extended root lobes, similar to the specimens of California, most Belgian teeth have strongly reduced lobes similar as observed on extant teeth. But although specimen BG01 is similar to the holotype M. applegatei, it equally resembles extant M. pelagios (Herman et al., 1993, plate 45-48, fig. $p$ ). Also specimens JJ01 (De Schutter, 2009, plate 4AF) and BD01 (op. cit., plate 6A-F) are morphologically very close to the more typical teeth of $M$. pelagios as figured in Yabumoto et al. (1997, figs 3 \& 5).

\section{Acknowledgements}

We would like to express our gratitude and thanks to the companies Investar (Antwerpen) and Groep Van Roey (Rijkevorsel) for allowing access to their construction site; to Gunther Cleemput (Ternat) for his technical support; to Marcel Vervoenen (Aalst), Robert Marquet (Antwerpen), Freddy van Nieulande (Nieuw en Sint-Joosland), Taco Bor (Sliedrecht), Frank Wesselingh (Naturalis, Leiden), Mark Bosselaers (Berchem) and Arie Janssen (Katwijk) for their useful suggestions; to Rene van der Vliet (Uden) for pursuing several megamouth teeth found by local collectors; to Jef De Ceuster (Wommelgem) for his assistance in the field; and finally David Ward (Orpington, UK) and an anonymous reviewer for their helpful comments and suggestions, which greatly improved the quality of this manuscript.

\section{References}

Adnet, S. \& Martin, R.A., 2007. Increase of body size in sixgill sharks with change in diet as a possible background of their evolution. Historical Biology, 19, 279-289. https://doi.org/10.1080/08912960701194461

Bengtson, P., 1988. Open nomenclature. Palaeontology, 31, 223-227.

Berra, T.M., 1997. Some 20th century fish discoveries. Environmental Biology of Fishes, 50, 1-12. https://doi. org/10.1023/A:1007354702142

Cappetta, H., 2012. Chondrichthyes. Mesozoic and Cenozoic Elasmobranchii: teeth. In Schultze, H.-P. (ed.), Handbook of Paleoichthyology, Volume 3E. Verlag Dr. Friedrich Pfeil, München, $1-512$.

Chandler, R. E., Chiswell, K.E. \& Faulkner, G.D., 2006. Quantifying a possible Miocene phyletic change in Hemipristis (Chondrichthyes) teeth. Palaeontologia Electronica, 9, 1-14.

Cleveringa, J. \& Schrijver, B., 2000. A model for shoreface deposition of Holocene prograded coastal deposits (Haarlem, The Netherlands), based on grain-size distributions and sedimentary structures. In Cleveringa, J., Reconstruction and modelling of Holocene coastal evolution of the Western Netherlands. Geologica Ultraiectina, 200, $113-132$.

Compagno, L.J.V., 1990. Relationships of the megamouth shark, Megachasma pelagios (Lamniformes: Megachasmidae) with comments on its feeding habits. In Pratt, H.L., Gruber, S.H. \& Taniuchi, T. (eds), Elasmobranchs as living resources: Advances in the biology, ecology, systematics, and the status of the fisheries. National Oceanic and Atmospheric Administration Technical Report NMFS, 90, 357-379.

Compagno, L.J.V., 2001. Sharks of the world: an annotated and illustrated catalogue of shark species known to date. Volume 2. Bullhead, mackerel and carpet sharks (Heterodontiformes, Lamniformes and Orectolobiformes). FAO Species Catalogue for Fishery Purposes, 1, $1-269$. 
Compagno, L.J.V., Dando, M. \& Fowler, S., 2005. A Field Guide to the Sharks of the World. Harper Collins, London, 1-368.

De Meuter, F. \& Laga, P., 1976. Lithostratigraphy and biostratigraphy based on benthonic foraminifera of the Neogene deposits in Northern Belgium. Bulletin Belgische Vereniging voor Geologie/Bulletin de la Société belge de Géologie, 85, 133-152.

De Meuter, F., Wouters, K. \& Ringele, A., 1976. Lithostratigraphy of Miocene sediments from temporary outcrops in the Antwerp City area. Professional Papers of the Belgian Geological Survey, 3, 1-19.

De Schutter, P., 2009. The presence of Megachasma (Chondrichthyes: Lamniformes) in the Neogene of Belgium, first occurrence in Europe. Geologica Belgica, 12, 179-203.

Everaert, S., 2014. Miocene afzettingen tussen de Boomse Klei en het Plioceen in het Churchilldok en Leopolddok (Antwerpse haven, rechteroever): een stratigrafische interpretatie. Afzettingen WTKG, $35,20-27$.

Everaert, S., De Schutter, P., Mariën, G., Cleemput, G., Van Boeckel, J., Rondelez, D. \& Bor, T., 2019. Een vroeg-miocene fauna uit het Zand van Kiel (Formatie van Berchem) bij Post X in Berchem (Antwerpen). Afzettingen WTKG, 40, 83-100.

Fernando, D., Perera, N. \& Ebert, D.A., 2015. First record of the megamouth shark, Megachasma pelagios, (Chondrichthyes: Lamniformes: Megachasmidae) from Sri Lanka, northern Indian Ocean. Marine Biodiversity Records, 8, e75. https://doi.org/10.1017/ S1755267215000512

Gonzalez-Barba, G. \& Thies, D., 2000. Asociaciones faunisticas de condrictios en el Cenozoico de la Peninsula de Baja California. Profil, 18, 1-4.

Herman, J. \& Marquet, R., 2007. Le Miocène du Deurganckdok à Doel. Memoirs of the Geological Survey of Belgium, 54, 1-149.

Herman, J., Crochard, M. \& Girardot, M., 1974. Quelques restes de sélaciens récoltés dans les Sables du Kattendijk à Kallo. I. Selachii - Euselachii. Bulletin de la Société belge de Géologie, 83, 15-31.

Herman, J., Hovestadt-Euler, M. \& Hovestadt, D.C., 1993. Part A: Selachii, No. 1b: Order: Hexanchiformes - Family: Chlamydoselachidae; No.5: Order: Heterodontiformes - Family: Heterodontidae; No.6 Order: Lamniformes - Families: Cetorhinidae, Megachasmidae Addendum 1 to No.3: Order Squaliformes; Addendum 1 to No.4 Order: Orectolobiformes; general glossary; summary part A. In Stehmann, M. (ed.), Contributions to the study of the comparative morphology of teeth and other relevant ichthyodorulites in living supraspecific taxa of Chondrichthyan fishes. Bulletin van het Koninklijk Belgisch Instituut voor Natuurwetenschappen, Biologie, 63, 185-256.

Hoedemakers, K. \& Dufraing, L., 2015. Elasmobranchii in de ontsluiting aan de luchthaven te Borsbeek (prov. Antwerpen, België). Afzettingen WTKG, 36, 2-19.

Hoedemakers, K. \& Dufraing, L., 2018. Een profiel bij Posthofbrug (Antwerpen). Afzettingen WTKG, 39, 65-80.

Keupp, H. \& Bellas, S., 2002. Miozän-Fossilien aus NW-Kreta III Die Beckenfazies. Fossilien, 19, 34-40.

Landini, W., Collareta, A., Di Celma, C., Malinverno, E., Urbina, M. \& Bianucci, G., 2019. The early Miocene elasmobranch assemblage from Zamaca (Chilcatay Formation, Peru). Journal of South American Earth Sciences, 91, 352-371. https://doi.org/10.1016/j. jsames.2018.08.004

Liu, S.Y.V., Joung, S.J., Yu, C., Hsu, H., Tsai, W. \& Liu, K.M., 2018. Genetic diversity and connectivity of the megamouth shark (Megachasma pelagios). PeerJ, 6, e4432. https://doi.org/10.7717/ peerj. 4432

Louwye, S., De Coninck, J. \& Verniers, J., 2000. Shallow marine Lower and Middle Miocene deposits at the southern margin of the North Sea Basin (northern Belgium): dinoflagellate cyst biostratigraphy and depositional history. Geological Magazine, 137, 381-394. https:// doi.org/10.1017/S0016756800004258

Louwye, S., Marquet, R., Bosselaers, M. \& Lambert, O., 2010. Stratigraphy of an early-middle Miocene sequence near Antwerp in Northern Belgium (Southern North Sea Basin). Geologica Belgica, 13, 269-284.

Marquet, R., 1984. Gids voor de ichnofossielen van België. Publicatie van de Belgische Vereniging voor Paleontologie, 4, 1-71.

Nichols, G., 2009. Sedimentology and Stratigraphy. $2^{\text {nd }}$ ed. WileyBlackwell, Chichester, 1-432.

Phillips, F.J., Welton, B.J. \& Welton, J., 1976. Paleontologic studies of the middle Tertiary Skooner Gulch and Gallaway Formations at Point Arena, California. In Fritsche, A.E., Ter Best, H. Jr. \& Wornardt, W.W. (eds), The Neogene Symposium. Pacific Section, Society of Economic Paleontologists and Mineralogists, San Francisco, 137154.

Purdy, R., Schneider, V., Appelgate, S., McLellan, J., Meyer, R. \& Slaughter, R., 2001. The Neogene sharks, rays, and bony fishes from Lee Creek Mine, Aurora, North Carolina, III. In Ray, C.E. \& Bohaska, D.J. (eds), Geology and Paleontology of the Lee Creek
Mine, North Carolina. Smithsonian Contributions to Paleobiology, 90, 71-202.

Reinecke, T., Louwye, S., Havekost, U. \& Moths, H., 2011. The Elasmobranch Fauna of the Late Burdigalian, Miocene, at WerderUesen, Lower Saxony, Germany and its relationships with Early Miocene Faunas in the North Atlantic, central Paratethys and Mediterranean. Palaeontos, 20, 1-170.

Shimada, K. \& Ward, D.J., 2016. The oldest fossil record of the megamouth shark from the late Eocene of Denmark and comments on the enigmatic megachasmid origin. Acta Palaeontologica Polonica, 61, 839-845. https://doi.org/10.4202/app.00248.2016

Shimada K., Welton B.J. \& Long D.J., 2014. A new fossil megamouth shark (Lamniformes, Megachasmidae) from the Oligocene-Miocene of the western United States. Journal of Vertebrate Paleontology, 34, 281-290. https://doi.org/10.1080/02724634.2013.803975

Sigovini, M., Keppel, E. \& Tagliapietra, D., 2016. Open nomenclature in the biodiversity era. Methods in Ecology and Evolution, 7, 12171225. https://doi.org/10.1111/2041-210X.12594

Spadini, V. \& Manganelli, G., 2015. A megachasmid shark tooth (Chondrichthyes, Lamniformes) from the Zanclean (early Pliocene) of San Quirico d'Orcia, central Italy. Bollettino della Societá Paleontologica Italiana, 54, 67-70.

Taylor L.R., Compagno L.J.V. \& Struhsaker P.J., 1983. Megamouth - a new species, genus and family of lamnoid shark (Megachasma pelagios, Family Megachasmidae) from the Hawaiian Islands. Proceedings of the California Academy of Sciences, 43, 87-110.

Tomita, T. \& Yokoyama, K. 2015. The first Cenozoic record of a fossil megamouth shark (Lamniformes, Megachasmidae) from Asia. Paleontological Research, 19, 204-207. https://doi. org/10.2517/2015PR004

Van den Bosch, M., 1966. De ontsluiting te Antwerpen - Ploegstraat. Mededelingen van de Werkgroep voor Tertiaire en Kwartaire Geologie, 1, 17-18.

Van Dijck, G., 2018. Boring 1405-B420752. Databank Ondergrond Vlaanderen. https://www.dov.vlaanderen.be/data/ boring/2018-160156.pdf, accessed 12/04/2019.

Watanabe, Y.Y. \& Papastamatiou, Y.P., 2019. Distribution, body size and biology of the megamouth shark Megachasma pelagios. Journal of Fish Biology, 95, 992-998. https://doi.org/10.1111/jfb.14007

Yabumoto, Y., Goto, M., Yano, K. \& Uyeno, T., 1997. Dentition of a female megamouth, Megachasma pelagios, collected from Hakata Bay, Japan. In Yano, K., Morrissey, J. F., Yabumoto, Y. \& Nakaya, K. (eds), Biology of the Megamouth Shark. Tokai University Press, Tokyo, 63-75.

Manuscript received 03.12.2019, accepted in revised form 09.02.2020, available online 17.02.2020. 

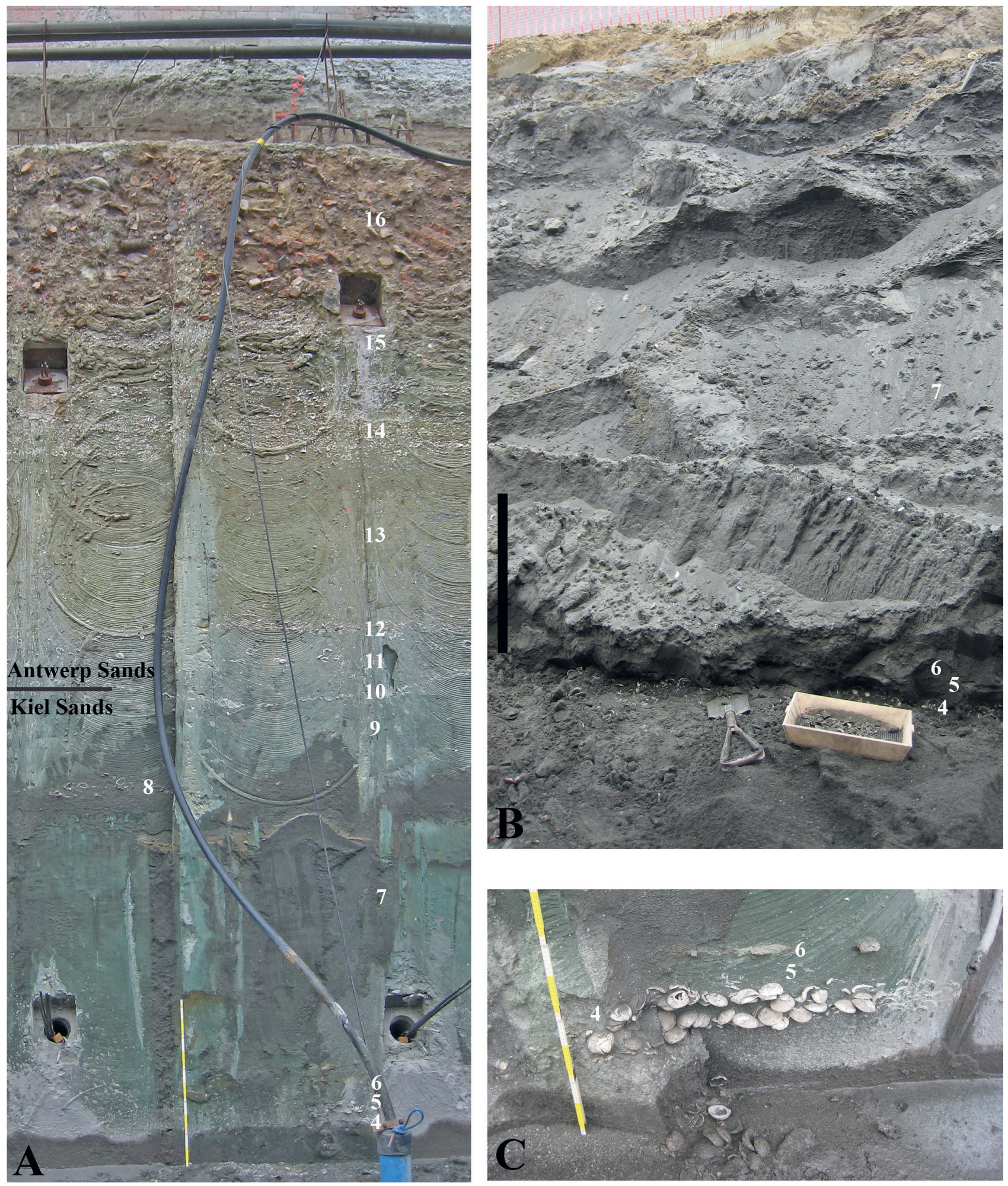

Plate 1. A. Argenta section; the profile is hardened with cement-bentonite, hence the unnatural colours. B. The Megachasma bearing horizon (unit 4), overlain by at least $2 \mathrm{~m}$ of grey, loose and strongly bioturbated sands of the Kiel Sand Member. Scale bar $0.5 \mathrm{~m}$. C. Detail of the taphocoenosis in unit 4. 

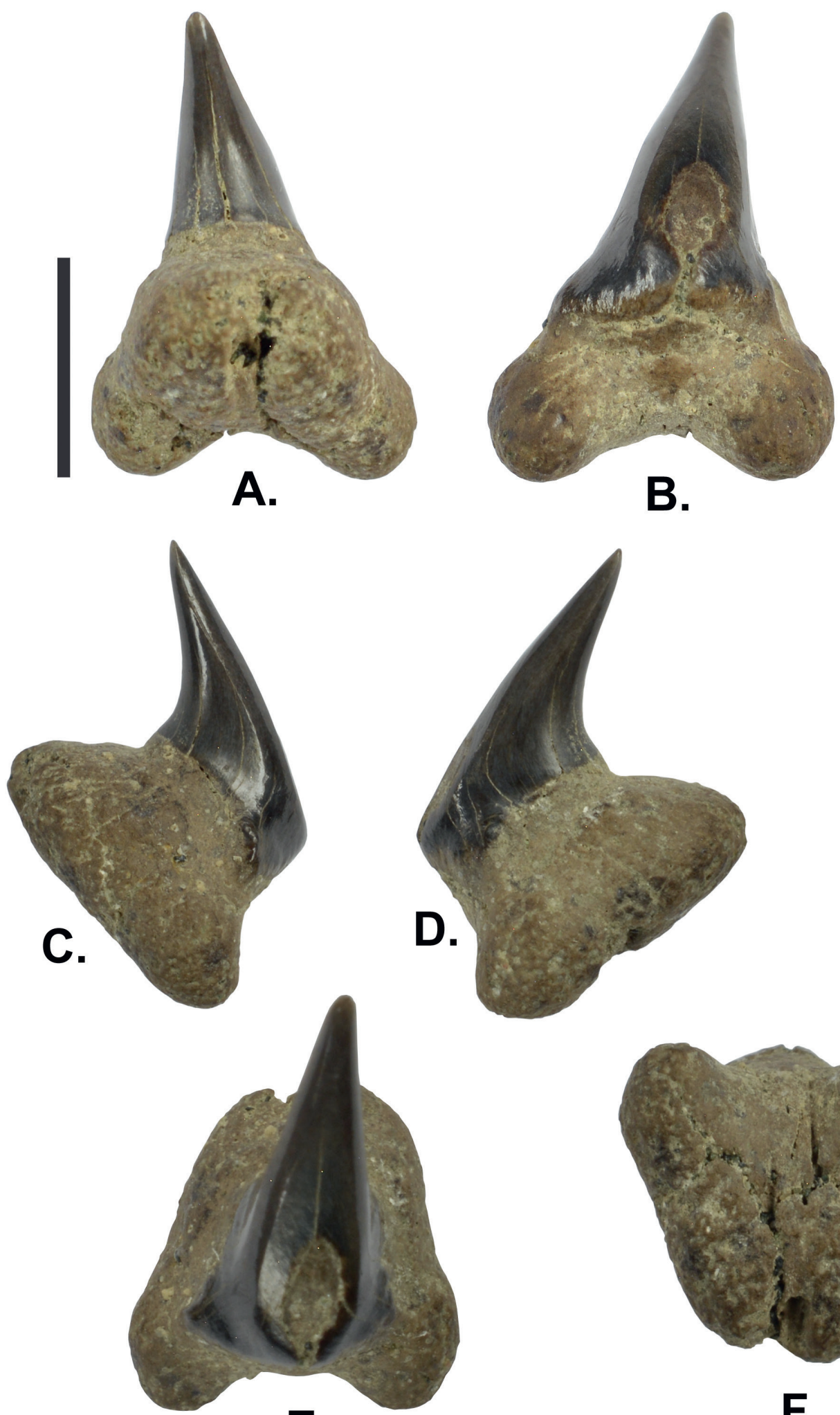

E.
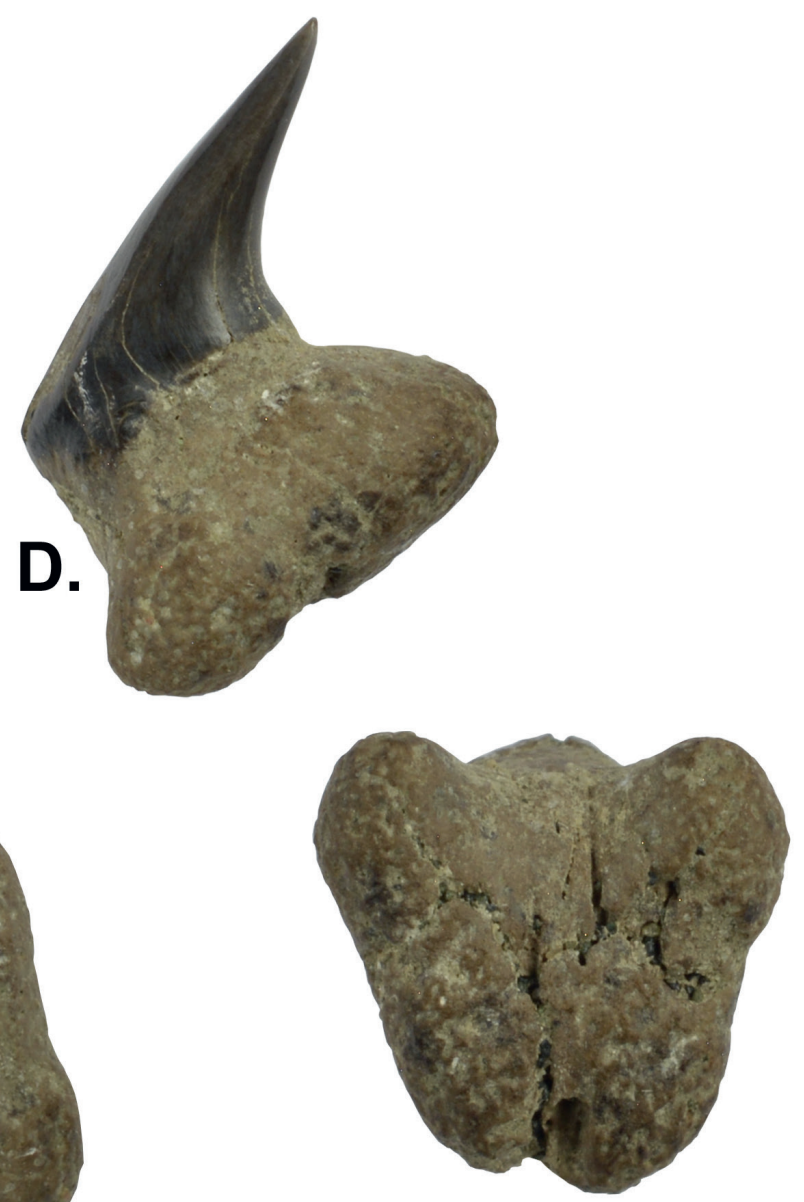

F.

Plate 2. (A-F) - IRSNB P 9946 - Megachasma aff. pelagios; lingual (A), labial (B), mesial (C), distal (D), apicolabial (E) and basal (F) views. Scale bar $5 \mathrm{~mm}$. 